\title{
A HADITH CONDEMNED AT PARIS REACTIONS TO THE POWER OF IMPRESSION IN THE \\ LATIN TRANSLATION OF AL-GHAZALI'S MAQĀṢID AL-FALĀSIFA
}

\author{
ANTHONY MINNEMA \\ SAMFORD UNIVERSITY
}

\begin{abstract}
of the more than two-hundred articles of the Parisian Condemnation of 1277 , one contains an arresting reference to a camel that is killed by a magician by means of sight alone through the power of the Evil Eye. While it is difficult to identify the sources of many doctrines in the edict with certainty, this article can be matched positively to a discussion of the soul's power of impression in the Latin translation of al-Ghazali's Maqāsid alfalāsifa. The concept of impression was condemned on account of its association with the Agent Intellect and the theory of emanation, but many philosophers preserved the illustrative example of the camel even when refuting the attendant argument. Unbeknownst to the Latin world, however, this statement about a camel does not originate with al-Ghazali, but with the Prophet Muhammad. This study traces the origin of the article in the Condemnation of 1277 back through Arabic and Persian worlds and examines its reception in the Latin intellectual tradition from the twelfth to the fifteenth century. It also demonstrates that, despite condemnation's influence and notoriety, its interpretation of this passage in al-Ghazali was not the dominant one in the Latin intellectual tradition. The majority of scholars instead interpreted this passage as al-Ghazali originally intended as an expression of speculative metaphysics, not magic.
\end{abstract}

\section{Key Words}

Al-Ghazali, Arabic-to-Latin translation, hadith, condemnation, emanation, magic. 
The Parisian Condemnation of 1277 is infamous in the history of medieval philosophy because it forbids the teaching of 219 doctrines at the University of Paris, though it neglects to mention the teachers, authors, or books that espouse these errors. ${ }^{1}$ This ambiguity has led to much speculation about the origins of these doctrines. ${ }^{2}$ As scholars since Roland Hissette's landmark study have shown, the majority of the condemned errors do not represent the opinions of scholars at Paris, but originate instead in arguments from Arabic-to-Latin translations of Aristotle and Arabic philosophers, which Latin philosophers raised for the sake of debate rather than as challenges to Christian dogma. ${ }^{3}$ While scholars have been able to connect only two-thirds of the doctrines to contemporary works with varying degrees of certainty, idiosyncratic phrases or words occasionally appear that provide a clear match. One arresting doctrine mentions the ability of impression given to souls by the Agent Intellect to kill a camel using the power of sight alone. Several aspects of the doctrine are potentially objectionable to a Christian audience which warrant its inclusion in the condemnation, yet the reference to a camel and killing it in such an unusual way makes this article unique and thus it can be traced to the Latin translation of al-Ghazali's Maqāșid alfalāsifa. However, the condemnation's authors could not have known that alGhazali agreed with them and that they were condemning a hadith of the Prophet Muhammad.

This study tracks al-Ghazali's camel and his discussion of impression in Latin, Arabic, and Persian worlds to find the source of this striking passage and to describe its reception in Latin Christendom. At a glance, it demonstrates the movement of a descriptive example about the effect of impression from one intellectual tradition to another, but the reality of this transfer is more complicated. Although al-Ghazali is the author of the Maqāsid al-falāsifa, he

1 This study was conducted with the support of many individuals and institutions. I would like to thank Thomas Burman and Charles Burnett, who read and offered comments at various stages of the project. I conducted research on the project with support from the University of Tennessee Humanities Center and the Warburg Institute at the University of London. I would like to thank Amos Bertolacci for his invitation to the Scuola Normale Superiore to speak on this project and the Latin readership of the Maqāṣid al-falāsifa in general. Of course, any errors are my own.

2 For a survey of the debate, see Kent Emery. and Andreas Speer, 'After the Condemnation of 1277: New Evidence, New Perspectives, and Grounds for New Interpretations,' in Jan A. Aertsen, Kent Emery and Andreas Speer (eds.), Nach der Verurteilung von 1277. Philosophie und Theologie an der Universität von Paris im letzen Viertel des 13. Jahrhunderts, (Miscelanea Mdiaevalia, 28), Berlin: de Gruyter, 2001, pp. 1-19.

3 Roland Hissette, Enquête sur les 219 articles condamnés à Paris le 7 mars 1277, Louvain: Peeters, 1977; Luca Bianchi, Il vescovo e i filosofi: La condanna parigina del 1277 e l'evoluzione dell'aristotelismo scolastico, Bergamo: Lubrina, 1990; Alain de Libera, Penser au Moyen Âge, Paris: Seuil, 1991. David Piché, La condamnation parisienne de 1277: nouvelle édition du texte latin, traduction, introduction, et commentaire, Paris: J. Vrin, 1999. 
derived much of its content from a Persian work by Avicenna and added examples, proofs, and explanations of his own. Some additions clarified Avicenna's argumentation, but this one was less successful because al-Ghazali's description of impression, particularly his choice of example, depicted the doctrine in a negative light that is absent in Avicenna's work, which had consequences for the Latin translation and its subsequent readers. Most medieval Latin readers objected to this passage, especially in later centuries, though for different reasons. Philosophers familiar with the Aristotelian context of impression understood that al-Ghazali was describing an intellective power of the soul and rejected it because of the espousal of celestial intelligences and the theory of emanation, which preserved the transcendent nature of a divine creator at the expense of his activity in creation. More superficial treatments of this passage, such as that of the Condemnation of 1277, inferred a supernatural quality to al-Ghazali's discussion of impression and condemned it instead as an expression of natural magic, though this interpretation was less popular. However they chose to refute the doctrine of impression, scholars often cited the example of the camel in the Latin Maqașid, and the doctrine and its evocative illustration became one of al-Ghazali's more infamous contributions to the Latin tradition of Aristotelian philosophy. Indeed, the reference to the camel may have been commonplace given the frequency of its appearance in works of varying academic genres.

\section{From Stephen Tempier to Muhammad}

Like most of the entries in the Condemnation of 1277, this article is no more than a sentence long and contains no bibliographical information to hint at its source:

'That superior intelligences impress (imprimunt) on inferior ones, just as one intellective soul impresses on another and also on a sense-perceiving soul, and through so great an impression a magician (incantator) casts a camel into a pit by sight alone.'

Despite the statement's brevity, there are clues that it is not of Latin origin. The first and most obvious is the mention of a camel, which is not native to Europe and therefore an odd choice as an example of a magician's power. The second is

\footnotetext{
4 'Quod intelligentiae superiores imprimunt in inferiores, sicut anima una imprimit in aliam, et etiam in animam sensitivam; et per talem impressionem incantator aliquis prohicit camelum in foveam solo visu.' See 'Articuli condempnati a Stephano episcopo parisiensi anno 1277', edited and translated by David Piché, in D. Piché, La condamnation parisienne de 1277, p. 112. In his facing French translation, Piché renders 'incantator' as 'magicien', ibid, p. 113. I followed this convention throughout rather than render 'incantator' literally as 'enchanter' in order to avoid confusion with the translation of 'fascinatio' as 'enchantment.'
} 
the incompatible language that seems to hint at translation, namely the verb imprimere, which points to a mental process (i.e. one soul affecting another) that does not correlate with the physical action of the magician, who moves an object through the power of sight. This brief article begs for more information as to its meaning and context-not only because of its sheer otherworldliness, but also because its offense is unclear. Is the condemnation objecting to this statement on philosophical grounds, as is the case with the majority of the articles in the edict, or because the doctrine invokes a natural magic at work in the world?

The source of this condemned article can be found in the last treatise of the Latin translation of the Maqāșid al-falāsifa in which al-Ghazali discusses the intellective powers that emanate into a strong soul that is well-attuned to the Agent or Active Intellect. ${ }^{5}$ This intellect is a feature of a Pseudo-Aristotelian doctrine that passed through several translations and intellectual cultures before it arrived in Latin Christendom. The doctrine of emanation was adapted by Arabic scholars from the work of Greek Neoplatonists as a philosophical concept that is sympathetic to monotheism, which subsequently immigrated to Latin Christendom through the translation movements of Aristotelian texts in the twelfth century. ${ }^{6}$ Emanation attempts to preserve the transcendent unity of the First Principle or God by removing it as the efficient cause in the process of creation. Instead, the First Principle emanates a sequence of increasingly inferior intelligences that possess more and more diversity and multiplicity, which in turn are responsible for the creation and maintenance of nine concentric celestial spheres, which gives the theory a deceptively astronomical quality. The last intelligence, the Agent Intellect, governs the sublunary world and emanates abilities to souls. A soul that is well-attuned to the Agent Intellect can possess the power to perform miracles, see visions, prophesy, and, in this case, impress its will upon other souls. Al-Ghazali describes this power in the following way:

'The passion of desire toward a body causes [the soul] to impress upon it. Sometimes the impression of a soul extends to a body so that it destroys a spirit and afflicts a man by means of the imagination, and this is called enchantment. There is a proverb regarding this - that the eye casts a man into a pit and a camel into a cauldron-and it is said 'it is true that men are enchanted [by the eye].' Yet the sense of the matter is that because a camel is pleasing to a man and he admires it, his soul is spiteful and jealous. He imagines the death of the camel and the camel's body is afflicted by his imagination and dies immediately. Since this is

5 Al-Ghazali, Algazel's Metaphysics: A Mediaeval Translation, ed. J. T. Muckle, Toronto, 1933, pp. 183197.

6 See Peter Adamson, The Arabic Plotinus: A Philosophical Study of the 'Theology of Arisotle', London: Duckworth, 2002, pp. 21-26, 137-55; Cristina D'Ancona, 'La doctrine de la création 'mediante intelligentia' dans le Liber de Causis et dans ses sources', Revue des sciences philosophiques et théologiques 76 (1992), pp. 209-33. 
A Hadith Condemned at Paris

possible, then it is not long before one soul [becomes] much more powerful than another. Sometimes it impresses on the body of the world, causing heat, cold, and motion, and from these three things all the prosperity of the world is derived."

The reference to the camel and its death at the hands of a superior soul reveals that al-Ghazali is the author of the article that appears in the Condemnation of 1277 , but the power of impression is different from what appears in the edict. The condemnation describes impression as a supernatural power that allows a magician to move an object by sight. Al-Ghazali, however, connects the phenomenon of impression to the notion of the Evil Eye, but he presents it as a proverb, not as a proof, and he explains its application so as not to imply that impression is supernatural. While al-Ghazali likens this power to a form of enchantment, he nuances this comparison by restating how impression is the natural faculty of one soul to affect another and even the world around it through the Agent Intellect. The condemnation misunderstands the passage because it sees telekinesis where al-Ghazali describes a metaphysical sort of mind-control. There is no magician in this passage from the Latin Maqāsid, yet impression remains an insidious power whereby a strong soul can kill camels and weaker-souled men by means of the imagination alone. Along with the theory of emanation, impression deserved to be condemned within the bounds of Christian doctrine, but not for the reason implied in the condemnation.

The proverb al-Ghazali mentions was instantly recognizable to his original audience, but less so for the condemnation's authors who failed to distinguish aphorism from argument. In fact, the appearance of this proverb and other examples like it in the Maqāsid al-falāsifa is important for our understanding of the work's development and context. Al-Ghazali looms large in the Islamic tradition as a virtuoso scholar who, as one of his projects, strove to domesticate elements of Aristotelian philosophy for the use of his fellow jurists. Maqāșid alfalāsifa forms a part of this project in that it serves as an introductory primer for Aristotelian philosophy. ${ }^{8}$ It provides an overview of the doctrines of logic,

'His autem affectus dilectionis erga corpus suum facit eam imprimere in illud. Aliquando autem impressio alicuius anime pertransit ad aliud corpus, sic ut destruat spiritum estimacione, et inficiat hominem estimacione, et hoc dicitur fascinacio. Et propter hoe est illud proverbium, quod oculus mittit hominem in fossam, et camelum in caldarium, et dicitur quod homines fascinari verum est; huius autem rei sensus hic est, quod quia multum placet ei camelus, et miratur de eo, et eius anima est maligna, et invidiosa, estimat casum cameli, et inficitur corpus cameli ab eius estimacione, et statim cadit; postquam autem hoc possibile est, tunc non est longe quin aliqua anima multo forcior quam ista, aliquando imprimat in hile mundi, faciens calorem, frigiditatem, and motum ex quibus tribus, scilicet calore, frigiditate, et motu derivatur omnis prosperitas huius mundi.' Al-Ghazali, Algazel's Metaphysics, 194.

8 There has been considerable debate regarding al-Ghazali's intention for the Maqāșid and its place within his corpus. For a concise survey of this debate and a new interpretation, see Ayman Shihadeh, 'New Light on the Reception of al-Ghazali's Doctrines of the Philosophers 
metaphysics, and physics, but unlike al-Ghazali's other works, he does not attempt to point out their philosophical or theological inconsistencies, as in the Tahäfut al-falāsifa. Al-Ghazali admits as much in the work's prologue. ${ }^{9}$ Yet alGhazali fails to mention that the Maqāṣid al-falāsifa is actually a loose translation of a Persian work by Avicenna, Dānesh-Nāmeh 'Ala'i. ${ }^{10}$ Rather than write an original work on the same subject, al-Ghazali took an existing text in a lessaccessible language and made a more-or-less faithful translation with some amendments to clarify Avicenna's dense argumentation. ${ }^{11}$ One alteration was the inclusion of the proverb about the camel and Evil Eye. Although Avicenna mentions the Evil Eye in the corresponding passage in the Dānesh-Nāmeh, he does so only in passing.

'It happens that some souls act by the power of imagination and the Evil Eye on the body of another person, or, that said, it is not forbidden by reason to believe that some men are endowed with a powerful soul that can exert considerable influence on a body of this world by their imagination and will, so that, under the force of this cause, a body of this world undergoes profound change, particularly on their warmth, cold and motion. From this proceed all miracles'. ${ }^{12}$

(Maqāșid al-Falāsifa), In the Age of Averroes: Arabic Philosophy in the Sixth/Twelfth Century, ed. Peter Adamson, London: Warburg Institute, 2011, pp. 77-92.

9 'I thought that I should preface an exposition of how they are incoherent with a concise discourse containing a reproduction of their intentions regarding the logical, physical, and theological sciences that they cultivate without distinguishing between the sound and the false in them. Thus, I intend only to make intelligible the ultimate ends of their doctrine without anything like expansion or addition going beyond what they intend. I will explain by way of accurate relation of facts and reproduction together with what they hold to be proofs. The book's object is the reproduction of the doctrines of the philosophers and that is its title.' alGhazali, Maqāșid al-falāsifa: Manțiq wa-'l-ilahyāt wa-țabīìya, ed. Suleyman Dunyā, Cairo: 1961, pp. 31-32.

10 Jules Janssens, 'La Dānesh-Nāmeh d'Ibn Sina: Un text à revoir?' Bulletin de philosophie médiévale 28 (1986), pp. 163-177, particularly pp. 163-164.

11 Jules Janssens, 'Al-Ghazzali and His Use of Avicennian Texts,' in Problems in Arabic Philosophy, ed. Miklós Maróth, Piliscsaba (Hungary): Avicenna Institute of Middle Eastern Studies, 2003, pp. 3749; Idem, 'Éléments avicenniens dans le livre al-Maqșad d'al-Ghazālī,' Mélanges de l'Institut Dominicain d'Études Orientales du Caire 30 (2014), pp. 91-103.

12 'Il arrive que certains âmes agissent par [la puissance de] l'imagination et du mauvais oeil sur le corps d'une autre personne, or, cela dit, il n'est pas interdit à la raison [de croire] que certains hommes soient doués d'une âme puissante qui puisse exercer une action considérable sur les corps de ce bas-monde --par leur imagination et leur volonté, de sorte que, sous l'effort de cette cause, les corps de ce monde subissent un changement profond, portant particulièrement sur leur chaleur, leur froid et leur mouvement. De là procèdent tous les miracles.' Avicenna, Le livre de science, 2 vols., ed. Mohammad Achena and Henri Massé, Paris: Les Belles Lettres, 1958, vol. 2, p. 87. 
Just as in the Latin Maqāsid, the soul that is well-connected to the Agent Intellect can influence the world around it and perform miracles, but the power of impression appears more benign in Avicenna's treatment since he does not describe its powers in such lurid terms, namely, the power to afflict men and kill camels. In this way, al-Ghazali's amendment to this passage represents a substantial deviation from Avicenna's description since he makes the power of impression appear substantially more malicious in its comparison to the Evil Eye.

Yet what al-Ghazali adds to Avicenna's text is significantly more than a common saying. In the Arabic Maqāsid al-falāsifa, the proverb in question appears as '[the Prophet], upon him blessings and peace, said 'the [evil] eye puts a man in the grave and a camel into the cooking pot' and 'the [evil] eye is a fact." ${ }^{13}$ What the text calls a proverb here are actually the words of Muhammad as recorded in hadith collections of varying soundness. The latter is attested in three of the six major hadith collections and was well-known to al-Ghazali's audience. ${ }^{14}$ The former, however, is found in more dubious collections of hadith, the earliest and most significant of which is the Hilyat al-awliya by Abu Nu'aym (d. 1038). ${ }^{15}$ This text is a collection of biographies of the companions of Muhammad, early religious leaders, and Sufis, and may have been popular in al-Ghazali's native Khurasan..$^{16}$ Though the hadith about the camel and the Evil Eye was the less sound of the two and appears in diverse works treating the words of the Prophet, this does not mean that this statement was less familiar to al-Ghazali's audience, since other eleventh-century scholars as distant as Ibn Hazm in al-Andalus knew of the saying. ${ }^{17}$

Arabic scholars were unaware of the origin of al-Ghazali's Maqāsid al-falāsifa in Avicenna. Few if any seem to have used the text, which survives in only a handful of copies. Not surprisingly, al-Ghazali's attempt at creating an accessible textbook of Aristotelian philosophy meant that the Maqāsid al-falāsifa was not as

'و هذه العلاقة العشقية هى الي تأثير ها عليه. وقد يتعدى أثر بعض النفوس إلى بدن آخر، حتى يفسد الروح بالتو هم، ويقتل الانسان 13

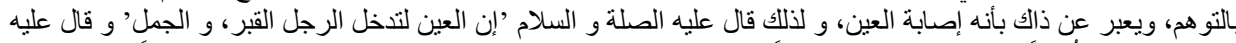

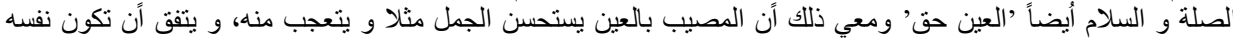
. Al-Ghazali, Maqāṣid al-falāsifa, pp. 381-382.

14 'العين تدخل الرجل القبر، و تدخل الجمل القدر'. Abu Nu'aym Ahmad ibn 'Abd Allah, Hilyat al-awliyā watabaqāt al-asfiyā, 10 vols., Beirut: Dār al-Kitab al-'Arabi, 1967, vol. 7, p. 90. See also Ismā̄îl b. Muhammad al-'Ajluni, Kashf al-khafā' wa-muzīl al-ilbās 'ammā ishtahara min al-ahậīith 'alá alsinat al-nās, 2 vols., Cairo, 1932-1933, vol. 2, p. 76; and Muhammad b. Yusuf Atțạfayyish al-Maghribi, Jāmi' al-shaml fì Hạdìth Khātam al-Rusul, 2 vols., Beirut, 1987, vol. 2, p. 49.

15 'Sahih al-Bukhari, vol. 7, bk. 71, n. 636; vol. 7, bk. 72, n. 827; Sahih Muslim, bk 26, n. 5426 and 5427; Sunan Ibn Majah, vol. 4, bk. 31, n. 3635, 3636, 3637.

16 Raif Georges Khoury, 'Importance et authenticité de textes de Hilyat al-awliya', Studia Islamica 46 (1977), pp. 73-113.

17 Muhammad Abu-Laylah, In Pursuit of Virtue: The Moral Theology and Psychology of Ibn Hazm alAndalusi (384 - 456 AH 994 - 1064 AD), London: TaHa Publishing, 1998, p. 96. 
popular in the Arabic world as the more argumentative Tahäfut al-falāsifa. ${ }^{18}$ Yet an introductory survey of Aristotelian philosophy was just what Latin scholars needed as they began to use works from that tradition. ${ }^{19}$ The Maqāsid al-falāsifa was translated at Toledo in the middle of the twelfth century by the circle of Dominicus Gundissalinus. ${ }^{20}$ The speed with which it travelled north to scholars at European universities, who began to cite this passage in the early thirteenth century, is a testament to its utility. However, al-Ghazali's project to domesticate elements of philosophy for theological use was lost on Latins, who possessed only this work from his massive corpus for more than four centuries.$^{21}$ Furthermore, almost all copies of the translation lacked the prologue in which al-Ghazali explained the nature and purpose of the work. ${ }^{22}$ Latin scholars quite reasonably assumed that al-Ghazali approved of the theologically-dubious arguments in the Maqāșid al-falāsifa , such as the eternity of the world, an afterlife without physical reward or torment, and the existence of an Agent Intellect that gave souls the ability to kill men and camels.

The appearance of quotations from theological sources was common enough in Arabic philosophical texts, yet al-Ghazali's decision to do so here demonstrates his wider agenda and one of his less successful amendments to Avicenna's text. He interjects a quotation from Muhammad not so much to reassure fellow jurists of his orthodoxy as for the sake of clarity regarding a heady discussion on the intellective powers of the soul. Unfortunately, this addition makes the power of impression seem malevolent, which appears to have affected Latin scholars, particularly the authors of the Condemnation of 1277 who imagined a magical power to be behind the power of impression. Though Latin scholars translated

18 Shihadeh, 'New Light', pp. 89-90.

19 Dominicus Gundissalinus primarily translated the works of Arabic philosophers in order to gain access to a living tradition of Aristotelian thought. See Charles Burnett, 'Arabic into Latin: the Reception of Arabic Philosophy into Western Europe', in Peter Adamson and Richard Taylor (eds.), The Cambridge Companion to Arabic Philosophy, Cambridge: Cambridge University Press, 2005, pp. 370-404 at pp. 373-375.

20 Anthony Minnema, "Algazel Latinus: The Audience of the Summa theoricae philosophiae, 11501600,' Traditio 69 (2014), p. 153-215; Charles Lohr, 'Logica Algazelis: Introduction and Critical Text,' Traditio 21 (1965), pp. 223-290 at pp. 228-29.

21 While Averroes' Tahäfut al-tahäfut was translated into Latin in the fourteenth century, it did not see widespread distribution until the late fifteenth century when Agostino Nifo published it with his commentary in 1497. However, the assumption that al-Ghazali was a disciple of Avicenna and Aristotle persisted into the sixteenth century. A revised edition of Nifo's work was republished with the title Destructio destructionum philosophiae Algazelis, which began to illuminate scholars to the differences between al-Ghazali and other Arab philosophers. Beatrice Zedler, Averroes' 'Destructio Destructionum Philosophiae Algazelis' in the Latin Version of Calo Calonymos, Milwaukee: Marquette University Press, 1961, pp. 18-31.

22 The one copy of the prologue exists in Paris, Bibliothèque nationale de France, MS Lat. 16096 and was edited and published by Dominique Salman in 'Algazel et les Latins,' Archives d'histoire doctrinale et littéraire du Moyen Âge 10 (1935-36), p. 103-27 at pp. 26-27. 
much of Avicenna's al-Shifa, they did not have access to the Dānesh-Nāmeh. It is telling that the authors of the condemnation chose to condemn this passage from al-Ghazali rather than similar discussions of impression in the translation of Avicenna's De anima. ${ }^{23}$ Al-Ghazali's arresting description of impression thus attracted the attention of Latin scholars, but it also opened up the possibility for confusion where Avicenna's treatment did not. The Latin translation of this passage further obscures its meaning by rendering the proverb anonymous. However, the omission of Muhammad from this statement appears wellintentioned rather than evasive since a reference to the Prophet here would be unnecessarily distracting and adds nothing to a Latin reader's comprehension.

\section{The Latin Reception of al-Ghazali's Discussion of Impression}

The camel that appears in the article on impression in the Condemnation of 1277 can be traced back to the Latin translation of al-Ghazali's Maqāsid al-falāsifa and then from the Arabic original to the Prophet Muhammad. The discussion of impression in Maqāṣid al-falāsifa originates in Avicenna's treatment of the same subject in the Dānesh-Nämeh, though his amendment to the passage portrays the power of impression in a dark light. The Latin reception of al-Ghazali's discussion of impression proves easy to track in many instances on account of the unique reference to the camel that often accompanies it. The anonymous inclusion of this doctrine in the Condemnation of 1277 makes it difficult to assess the work's effect on the reading of the Latin Maqāsid. However, another thirteenth-century condemnation attributed to Giles of Rome, De erroribus philosophorum, listed sixteen errors in the Latin translation of al-Ghazali's work, the last of which was the power of impression. ${ }^{24}$

'Again [al-Ghazali] erred in regard to the activity of our soul, holding that the soul operates in other bodies through the imagination, and that 'the impression of the soul extends to other bodies in such a way that it destroys a spirit and kills a man by its judgment, and this is said to be enchantment.' On this account, according to him, this is a true 'proverb, that the eye casts a man into a pit and casts a camel into a cauldron.' All these things are clear from what he says in the fifth treatise of his Physics. ${ }^{25}$

23 Avicenna offers a lengthy treatment of impression as a faculty of the intellective soul in his De anima. While he discusses an 'enchanting eye' ('opus oculi fascinantis et aestimationis operantis'), he does not describe it in as lurid terms as al-Ghazali, thus keeping the discussion firmly on a philosophical plane. Avicenna, Liber de anima seu sextus de naturalibus ed. Simone van Riet, 2 vols., Louvain-Leiden: E.J. Brill, 1968-1972, vol. 1, pp. 64-66. See also n. 43-44.

24 Giles of Rome, De erroribus philosophorum, edition and translation by Josef Koch and John Riedl, Errores Philosophorum: Critical Text with Notes and Introduction, Milwaukee: Marquette University Press, 1944, pp. 38-46.

25 'Ulterius erravit circa actionem animae nostrae ponens animam per imaginationem operari in corpore alieno, et quod 'impressio animae transeat ad aliud corpus, sic ut destruat spiritum per 
The author of this work copies the passage on impression almost verbatim and preserves the definition and the illustrative example of the Evil Eye. Conversely, the Condemnation of 1277 paraphrases the passage and makes some additions that confuse the doctrine's meaning. Though De erroribus philosophorum carried less authority and enjoyed less circulation than the Condemnation of 1277, the bibliographical information it provides makes it more useful since it also provides the error's author and identifies where the error occurs in the author's work. More importantly, this work makes no mention of a magician that appears in the Condemnation of 1277 , but merely an act of the imagination, which keeps the discussion within the philosophical realm rather than the supernatural.

The majority of scholars follow the interpretation of De erroribus philosophorum and see the proverb as al-Ghazali intended-as a way to explain a power of the intellective soul. ${ }^{26}$ This is the case especially among al-Ghazali's readers from the first half of the thirteenth century, though they often cite him anonymously. For example, William of Auvergne says 'when we wish to understand this concept [of impression], consider the strength of the imaginative faculty, from whose operation follows external operation by necessity, just as a philosopher said concerning the same matter that 'a certain philosopher said about a certain person who imagined the death of a camel and the camel fell immediately." ${ }^{27}$ William omits al-Ghazali's name and does not mention a proverb, though he connects the concept to the imagination. Peter of Spain gives a more fulsome account of al-Ghazali's notion of impression, though again anonymously.

'Therefore, it seems that this action [of impression] is practiced by administering things, but forms are drawn from a bulk of matter. For not only is a soul believed to induce impression on its own body, but also on another's, whence the command of enchantment of a malign soul dissolves a body, impressing corruption, for as it

aestimationem suam et interficiat hominem, et hoc dicitur esse fascinatio.' Propter quod secundum ipsum verum est hoc 'proverbium, quod oculus mittit hominem in fossam et camelum in caldarium.' Haec autem omnia patent ex his quae dicit in tractatu $v^{\circ}$ Scientiae suae Naturalis.' Giles of Rome, De erroribus philosophorum, p. 44.

26 This interpretation was helped by the fact that Avicenna offers a similar discussion of impression in book four of De anima, also translated by the scholars who translated the Maqāsid. Indeed, Latin scholars recognized so much overlap between the arguments of these scholars that they referred to al-Ghazali as the summarizer and follower of Avicenna. However, Avicenna does not mention a camel and thus al-Ghazali retained some utility in the minds of scholars despite the similarities between the authors' discussions. Minnema, 'Algazel Latinus,' pp. 180-181.

${ }_{27}$ 'Cum autem volueris ad lucidum hoc intelligere, cogita fortitudinem imaginativae virtutis, ex cuius operatione sequitur ex necessitate forinseca operatio, quemadmodum dixit quidam philosophus de quodam qui imaginabatur casum cameli et statim cecidit camelus.' William of Auvergne, De universo creaturum, in Guilielmi Alverni opera omnia, ed. Blaise Le Feron, Paris, 1674, f. $615 \mathrm{c}$. 
A Hadith Condemned at Paris

is said commonly [vulgo] that 'the Evil Eye delivers a man to a pit and a camel into a cauldron.' But this seems discordant with truth'. ${ }^{28}$

Unlike William, Peter emphasizes the malicious nature of this power of the soul implied by al-Ghazali's choice of example and thus the authors of the Condemnation of 1277 were not alone in their negative reading of this passage. Peter acknowledges the similarity between impression and enchantment that appears in the Latin Maqāsid and De erroribus philosophorum, but his focus on the powers of the mind indicates that he places the power within the realm of philosophy or psychology rather than magic. Peter's choice of the word 'vulgo' is significant in that he suggests that this saying about impression was well-known which finds support in comments by later scholars. However, the connections between impression, this saying, and al-Ghazali was not widely recognized until the second half of the thirteenth century.

A single early exception where al-Ghazali is quoted by name is in Robert Grosseteste's commentary on Galatians 3:1, in which he compares the variety of enchantments that Paul might have meant when he asked 'Who has enchanted you that you do not obey truth?'29 Grosseteste is surprisingly nuanced in his treatment of this concept, prefacing the discussion by saying that it is not easy to say whether enchantment, as the common people understand it, exists or not'. ${ }^{30}$ He provides several instances ranging from the classical example of the basilisk to Aristotle's examples of women breaking mirrors with a look, as well as other philosophical discussions of impression in the works of Avicenna and alGhazali. Though Grosseteste copies out the passage from al-Ghazali in full, he argues that Paul uses the 'vulgar' meaning of enchantment and does so metaphorically rather than specifically referring to the power of impression described by the Arabic authors. ${ }^{31}$ Thus, he implies a distinction between impression and enchantment, with the latter understood to be more supernatural and associated with the interpretation of the common people. This

28 '[V]idetur igitur hec actio eis procurantibus exerceri, figure vero ex magnitudine materie educuntur, non solum vero censetur anima in corpore proprio inpressiones inducere, set etiam in extraneo, unde anime maligne ductus fascinationis corpus dissipat et corruptionem inprimendo, vulgo enim dicitur oculum malum hominem fosse mandare et camelum caldario. Set videtur hoc dissonum veritati.' Peter of Spain, Scientia libri de anima, ed. Manuel Alonso Alonso, Madrid: CSIC , 1941, p. 476.

29 'O insensati Galatae, quis vos fascinavit non obedire veritati,' in Robert Grosseteste, Expositio in epistulam sancti Pauli ad Galatas, ed. Richard Dales, CCCM 130, Turnhout: Brepols, 1995, pp. 71-74 at p. 71.

30 'Sed an fascinatio, sicut illam intelligit uulgus, sit aliquid uel non sit, non facile dixerim.' Robert Grosseteste, Expositio ad Galatas, p. 73.

31 'Sed quomodocumque se habeat circa hoc veritas, Apostulus non intendit aliud nisi assumere hoc nomen ab usu uulgi et uti eo metaphorice in designationem corporis infecti ex inuidia tabescente.' Robert Grosseteste, Expositio ad Galatas, p. 74. 
recognition of distinctions between different types of enchantment and between enchantment and impression makes Grosseteste unique among the Latin readers of al-Ghazali, since most scholars do not interject as many gradations between these phenomena and view them as either philosophical or magical in nature.

Even before the condemnations and systematic refutations of Aristotelian thought began to appear with greater frequency in the later thirteenth century, scholars reacted differently to al-Ghazali's discussion of impression and the accompanying proverb of the Evil Eye. William of Auvergne recognizes that alGhazali was discussing an intellectual phenomenon and was untroubled by the theological implications. Grosseteste is neutral on the subject, admitting that it is difficult to argue for or against its existence, and acknowledges a distinction between the type of power described in al-Ghazali's work and other forms of enchantment. On the other hand, Peter of Spain stresses the use of impression by a wicked soul for evil purposes. Despite this variety of reception, however, none of these authors associate the power of impression with a magician or the supernatural realm as described in the Condemnation of 1277.

Scholars began to connect al-Ghazali by name to the concept with more consistency in the latter half of the thirteenth century, often preserving the reference to the death of the camel in their quotations. Important examples of this treatment appear in the works of two Franciscan masters at Paris who cited al-Ghazali and his camel in their responses to quodlibetal questions on the powers of the soul. When John Pecham addresses the question of whether the intellect can be transferred by affect or the human will, he references Avicenna and al-Ghazali's discussions of impression and cites the latter's example of the soul's ability to kill a man or a camel, though he says that the philosophers' positions are erroneous..$^{32} \mathrm{He}$ makes no mention of the comparison of the concept to enchantment. Richard of Middleton likewise mentions al-Ghazali with Avicenna while discussing the question of impression and quotes the passage from the Latin Maqāșid in full. ${ }^{33} \mathrm{He}$ comes to the similar conclusion that both are in error, but he argues that impression is an offense to the truth of the faith rather than philosophical truth. In treating al-Ghazali's concept of impression as

32 'Item, Algazel: "Aliquando impressio alicuius animae pertransit ad aliud corpus, cum scilicet aestimat et inficit hominem;" et consequenter dicit quod sola cogitatione maligna facit cadere camelum ... Ad verba Avicennae et Algazelis et libri De causis dico omnia sunt erronea et falsa, ut declaratum est.' John Pecham, Quodlibet Romanum, ed. Ferdinand Delorme, Rome, 1938, Q. IV, q. XXX, pp. 243-244.

33 'Huius etiam erroris fuit Algazel: sicut patet suo libro physicorum libro quinto capitulo. 9. Ubi dicit sic quod 'aliquando impressio alicuius anime transit ad aliquod corpus ... Et eius anima est maligna et invidiosa estimat casum cameli ab eius estimatione et statim cadit.' Sed Avicenna et Algazel in illis opinionibus valde turpiter erraverunt. Plura enim in illis opinionibus sunt contra fidei veritatem.' Richard of Middleton, Authorati theologi Ricardi de media villa: Quodlibeta, Venice, 1509, Quodlibet III, q. 12, fol. 35. 
an error, these scholars represent a uniform shift in opinion that became widespread from the late thirteenth century onwards. It is also important to emphasize that John Pecham and Richard of Middleton are referring to alGhazali's discussion of impression and his example of the camel in a public debate where the academic audience is expected to have a general knowledge of a question's arguments and their sources. In this way, these two Franciscans echo Peter of Spain's suggestion that this proverb was well-known among scholars, though unlike Peter, they do not mention the proverb anonymously.

References to al-Ghazali and his discussion of the power of impression persist into the fourteenth century and in increasingly unlikely places. Peter of Abano mentions this passage in his Conciliator as he describes the differing opinions of philosophers and doctors regarding how sperm impregnates a woman. $\mathrm{He}$ invokes al-Ghazali with regards to the power of the intellect in impregnation.

'Why is the likeness of the begotten to the father less in some men than others? Since a man engages his soul in intercourse in many ways, for after a father and mother have engaged in intercourse, they then influence the begotten. [Philosophers] have said many things concerning the vigor of the imagination, Avicenna extensively in the fourth chapter of De anima and al-Ghazali, his colleague, such as a man is thrown down into a well and a camel into a cauldron, so that [the imagination] acts not only upon its own body, but also in another's. Therefore, it is not a wonder if it, as sperm and menses, is able to transform passible matter to the same degree, ${ }^{34}$

Peter's usage here is striking for several reasons. Unlike his contemporaries in the fourteenth century, he does not immediately reject the concept of impression as part of the doctrine of emanation. Yet he also takes the concept out of its metaphysical context in order to propose a rather ingenious solution for the question of physical similarities between generations. In an age before genetics, he intuits that there must be some power that men and women possess that allows them shape the appearance of their offspring and, comparing the positions of philosophers and medical scholars, he suggests that this occurs by means of intellective force. This repurposing of impression is unique to Peter of Abano and does not find an echo in other sources, but it demonstrates that al-

34 'Cur in hominibus minor sit assimilatio geniti ad generans, quam in caeteris animi alium? Quoniam homo multifariam suam animam disponitur in coitu, postquam enim quod pater et mater in coitu fuerint dispositi, ita afficiuntur genita. De vigore quoque imaginationis quam plurima locuti sunt, Avicenna maxime de anima 4 et Algazel ipsius collega volentes, ut ui imaginationes intensae deiiciatur homo in puteum, et camelus in caldarium ita, ut operetur non solum in corpore proprio, verum et in alieno. Et ideo non est mirum si materiam passibilem adeo, ut sperma et menstruum valeat immutare.' Peter of Abano, Conciliator differentiarum quae inter philosophos et medicos versantur', Venice, 1565; reprinted Padua: Antenore, 1985, Differentia 37, f. $56 \mathrm{v}$. 
Ghazali's descriptions of a complicated philosophical concept could break outside of its immediate context and was applied by scholars in novel ways.

Given these references and their variety of application, it is possible that alGhazali's camel may have been a commonplace reference among universitytrained scholars, even if they considered the idea of impression to be an error. However, the assertion of the popularity and comprehension of al-Ghazali's camel is not without difficulty. Nicolas Oresme exchanged the camel for a mule and attributed this example to Avicenna in De causis mirabilium. ${ }^{35}$ This confusion was furthered by a later commentator of Oresme's works, Claude Rapine, who replaced 'mulum' with 'nudum' when discussing this passage. ${ }^{36}$ However, this same commentator realized his mistake when he translated Oresme's work into French and subsequently returned the camel. ${ }^{37}$ There are also instances where scholars discussed al-Ghazali's concept of impression without referring to his example of the Evil Eye. The most prominent among these are Albertus Magnus and Peter John Olivi, who refer to al-Ghazali while discussing on the powers of the soul and make no mention of a camel..$^{38}$ These philosophers demonstrate an understanding of impression as it appears in al-Ghazali as a part of the theory of emanation, and both of them reject the concept. ${ }^{39}$

In each of these cases, scholars understood al-Ghazali's discussion of impression in the context of speculative metaphysics. They commonly referred

35 'Quid autem scivit Avicenna utrum illud quod ibi ponit sit verum, scilicet quod ymaginatio fecit cadere mulum et cetera? Unde fuerunt alii quam Avicenna et Agazel et quidam alii qui posuerunt quod materia obedit intellectui non solum in eodem subiecto set et in diversis. Sed quia michi videtur esse pure contra philosophum, ideo non plus et cetera.' Nicole Oresme, De causis mirabilium, in Nicole Oresme and the Marvels of Nature, ed. Bert Hansens, Toronto: Pontifical Institute of Mediaeval Studies, 1985, p. 314.

36 'Non tamen praesumo cum Avicenna asserere species huiusmodi etiam localiter corpus posse movere, sicut de quo allegat, qui per imaginationem nudum in foveam praecipitavit.' Claude Rapine, De his quae mundo mirabiliter eveniunt, Paris, 1542, 19v-20r.

37 Claude Rapine, Des choses merveilleuses en nature, Lyon, 1557, 112.

38 'Sed hoc attendendum esse videtur, quod secundum Avicenna et Algazelem, non tantum a caelestibus fiunt huiusmodi motus, sed etiam ab animalibus: quia illi dicunt animam unius imprimere per modum fascinationis in animas multorum aliorum, sed hoc per philosophiam probari vix posset.' Albertus Magnus, De somno et vigilia, in Beati Alberti Magni opera omnia, ed. A. Borgnet, vol. 9, Paris, 1890, p. 133. 'Quod igitur Algazel et Avicenna et consimiles in hac parte finxerunt quam sit frivolum patet, et maxime quia, ex quo iustitia et vitium, gloria et confusio proprie in nobis esse non possunt, quare de praedictis curabimus, et non potius omnibus sit pro lege voluntas? Ad vicesimum tertium dicendum quod falsissimum est superiores potentias mentis nostrae sic sequi variationes corporis et impressiones corporum caelestium et elementarium aut ab eis diversimode immutari sicut inferiores potentiae immutantur.' Peter John Olivi, Quaestiones in secundum librum Sententiarum, ed. B. Jansen, vol. 2, Rome, 1924, q. 57, p. 369.

39 See Dag Hasse, Avicenna in the Latin West, London: Warburg Institute, 2000, pp. 165-174, particularly pp. 168-172 regarding the wider treatment of 'impressio' and 'fascinatio.' 
A Hadith Condemned at Paris

to the concept as impressio and, while some likened it to enchantment or fascinatio, most clarified how this phenomenon was a faculty of the intellect or at least did not give an indication that it was to be understood as magic. The only reading that approaches that of the Condemnation of 1277 is in the fifteenthcentury inquisitors' manual by Heinrich Kramer and Jacob Sprenger, Malleus Malleficarum, which calls attention to topics of the Evil Eye and enchantment in the works of Avicenna and al-Ghazali.

'With regards to other arguments where it is proven that sorcerous effects can be caused by old women without the work of demons, it ought to be said that it is discordant to reason to draw conclusions from a particular example. Since in all of the Holy Scriptures, it seems, no such thing is found except where it concerns the enchantment or evil facial expressions of old women, it is not valid to conclude therefore that it always has to happen in such a way...The third way is that a change for the worse occurs as a result of such hatred in the body of someone through the eyes of someone else looking at him. The doctors commonly make statements in this way about enchantment, following in the same way that Avicenna and al-Ghazali said, as it is deduced in the arguments'. ${ }^{40}$

This reference to al-Ghazali's concept of impression has similarities to Grosseteste's treatment of enchantment since the authors list the various interpretations of fascinatio. Yet the term impressio is not mentioned, nor do the authors qualify al-Ghazali's understanding of enchantment, leaving open the interpretation of the phenomenon as sorcery. Shortly after this passage, the authors quote from the Condemnation of 1277 to emphasize that the doctrine has already been rejected in centers of learning.

'Additionally, an article has been condemned in many universities, especially that of Paris, that a certain magician casts a camel into a pit by sight alone, because, just as superior intelligences impress upon inferior ones, so too does the intellective soul impress on another and also on a sense-perceiving soul' ${ }^{41}$

40 'Ad alia vero argumenta in quibus probatur maleficiales effectus posse absque opere demonum a vetulis procurari, dicendum quod ex vno particulari concludere varie est dissonum rationi. Et cum in tota, vt videtur, scriptura sacra non inuenitur tale nisi hic vbi agitur de fascinatione seu inuultuatione vetularum, ideo non valet per hoc concludere quod semper habeat ita euenire...tercio, quod ex tali odio fiat immutatio ad malum in corpore alicuius per oculos alterius aspicientis in eum, de fascinatione hoc modo dicta communiter loquuntur doctores, secundum quem modum etiam Avicenna et Algazel, ut in argumentis deducitur, locuti sunt.' Heinrich Kramer and Jacob Sprenger, Malleus Maleficarum, 2 vols., ed. Christopher MacKay, Cambridge, 2006, vol. 1, 17B-17C, pp. 235-236.

41 'Preterea, est articulus condemnatus in plerisque vniversitatibus, precipue tamen Parisiensi, quod incantator aliquis proicit camelum in foueam solo visu, eo quod, sicut intelligentie superiores imprimunt in inferiores, sic anima intellectiua imprimit in aliam et etiam in animam sensitiuam.' Institoris and Sprenger, Malleus Maleficarum, vol. 1, 17D, p. 237. 
While the quotation of the condemnation indicates that intelligences play a role in enchantment, it also suggests that the authors believe that it is a form of witchcraft rather than an expression of speculative metaphysics. Indeed, they rearrange the article as it appears in the condemnation so that the example is now the major premise. The action of the magician is not used as something to explain enchantment; it is enchantment. The subsequent mention of intelligences thus reads as the metaphysical underpinning for the magician's sorcery and not as the primary error of the article. The rearrangement of the article and the connection drawn between enchantment and al-Ghazali imply that Kramer and Sprenger considered impression to be sorcery.

However, the authors of the Malleus mention that they discussed al-Ghazali in arguments concerning this subject earlier in the text, whose contents reveal that they see enchantment differently from what the above passages suggest. These arguments pertain to the question of whether witches perform sorcery on their own or always require diabolic assistance. ${ }^{42}$ Al-Ghazali's appearance in this discussion is not as fulsome as above and he is named merely as one of the authorities who agrees with Avicenna on the matter of the Evil Eye. ${ }^{43}$ Yet the authors relate that Avicenna believes the imagination can change or seem to change extraneous objects, such as when one's sense of balance is affected by heights or when one feels fear at seeing a dead body. ${ }^{44}$ After the presentation of these arguments, the authors conclude that the phenomena that philosophers describe are not magical nor do they require the devil.

42 'An catholicum sit asserere quod ad effectum maleficialem semper habeat demon cum malefico concurrere vel quod vnus sine altero, vt demon sine malefico vel e converso, talem effectum possit producere.' Institoris and Sprenger, Malleus Maleficarum, vol. 1, 13D, p. 229.

43 'Est ad hoc etiam Avicennae Sexto Naturalium li iii. c. vltimo ita dicens, 'Multotiens autem anima operatur in corpore alieno, sicut in proprio, quemadmodum est opus oculi fascinantis et aestimationis operantis. Et eandem sententiam etiam ponit Algazel li. v suo Phisicorum, c. ix.' Institoris and Sprenger, Malleus Maleficarum, vol. 1, 14C, p. 231.

44 'Putat etiam Avicenna, licet non teneatur in illo, quod virtus ymaginativa etiam absque visu possit extranea corpora immutare, vbi nimis extendit virtutem ymaginativam, et capimus hic virtutem ymaginativam non in quantum distinguitur contra alias virtutes sensitivas interiores, vt est sensus communis et fantasia et estimatio, sed inquantum includit omnes illas virtutes interiores. Sed bene verum quod talis virtus ymaginativa potest transmutare corpus coniunctum, scilicet illud in quo est, sicut homo potest ambulare supra trabem que est in medio vie, si vero posita fuerit super aquam profundam, non audebit ambulare super eam, eo quod ymaginabitur in eius anima forma cadendi vehementer impressa, cui obedit material eius et virtus membrorum eius et non obediunt eius contrario, scilicet ad directe ambulandum. In hoc ergo convenit hec immutatio cum oculo fascinantis inquantum immutatur corpus proprium primo, sed non corpus alienum, de qua immutatione iam loquimur...Item homo viuens et prope cadauer hominis occisi transiens etiam non sentiendo illud adhuc terrore concutitur.' Institoris and Sprenger, Malleus Maleficarum, vol. 1, 14C-14D, p. 231. 
A Hadith Condemned at Paris

'There are some things in nature that have certain hidden powers, whose reasoning man does not know, such as when iron attracts steel and many other things that Augustine mentions in the twentieth book of the City of God. In the same way women sometimes can make use of certain things in order to bring about changes in the bodies of others without the aid of devils, which exceed our reasoning. And because these exceed [our reasoning] we must not ascribe them therefore to devils as if they were associating with witches at the same time. ${ }^{45}$

This warning to readers that not all unexplained events are witchcraft signify that the authors ultimately do not believe that the powers described by Avicenna and al-Ghazali ought to be interpreted as supernatural, despite the implications of the previous passages and the reworking of the article from the condemnation. This leaves the Parisian edict as perhaps the sole medieval source that strongly implied the interpretation of al-Ghazali's impression as a form of magic. Moreover, the appearance of the article in the Malleus provides an example of how the ambiguous treatment of the doctrine in the Condemnation of 1277 could generate confusion in later works.

Al-Ghazali's discussion of impression continued to be a point of reference after the condemnations of the thirteenth century at Paris and Oxford. On the whole, scholars became less generous to al-Ghazali, unlike early readers such as William of Auvergne and Robert Grosseteste, and the majority refuted the argument as a part of the wider rejection of emanation. In most instances, scholars treated al-Ghazali's doctrine of impression as a legitimate, if flawed philosophical discussion and did not connect it to magic. It is only with the Condemnation of 1277 that authors made explicit the connection between impression and a supernatural act performed by a magician. One exception arises in the Malleus Maleficarum, but this does not appear to have been the authors' intention. In citing the condemnation on this matter, the Malleus Maleficarum offers a confusing interpretation of enchantment in one passage, but elsewhere indicates that the intellective powers of the imagination need not be understood as sorcery. Thus, the Condemnation of 1277 stands outside the mainstream of philosophical thought on this matter, despite the influence that it possessed.

We have traced al-Ghazali's discussion of impression, along with the proverb of the camel, across Latin Christendom as well as the Arabic and Persian Near East. The durability of the discussion of the doctrine of al-Ghazali within the Latin

45 'Praeterea, sicut res naturales habent quasdam virtutes occultas quarum ratio ab homine assignari non potest, sic ut quod adamas trahit ferrum et multa que Augustinus enumerat xxi De Civitate Dei, ita mulieres ad immutationes faciendas in corporibus alienis certis rebus vti possunt absque auxilio demonum. Que etiam nostram rationem excedunt, et quia excedunt non debemus propterea demonibus quasi ex maleficis insimul conuersantes ascribere.' Institoris and Sprenger, Malleus Maleficarum, vol. 1, 14D-15A, pp. 231-232. 
intellectual tradition can be attributed in no small way to al-Ghazali's decision to add this evocative proverb to his Arabic translation of Avicenna's Persian text. Al-Ghazali intended for the proverb to clarify an opaque facet in the theory of emanation, not to grab scholars' attention. Yet in emphasizing impression's similarity to the Evil Eye, he opened up the possibility to interpret it as a malevolent, supernatural power. That he was quoting the words of Muhammad mitigated this possibility with his intended Arabic audience. The Latin translation of the Maqāșid al-falāsifa exacerbated the potential to misinterpret alGhazali's intended meaning for impression. This became a reality in the Condemnation of 1277 , which stressed the supernatural nature of impression by inserting a magician that does not appear in al-Ghazali's text. The condemnation's rendering of this passage threatened to alter the Latin reading of al-Ghazali in this regard, as can be seen in the quotation of the edict in the Malleus Maleficarum, which infelicitously exchanges the Evil Eye for the faculty of impression as the major error in the doctrine. However, the condemnation's reading of al-Ghazali was not dominant within the Latin tradition. Most scholars raised the discussion of impression in al-Ghazali only to refute it on philosophical and theological grounds, and few of them cited the condemnation. The condemnation's lack of influence in this regard can be attributed to the fact that al-Ghazali is not named in the article, though this is perhaps too charitable to the edict at the expense of scholars' abilities. Indeed, the scholars who treated this matter read al-Ghazali closely as the wording of proverb deviated only slightly in Latin scholarship over the centuries. ${ }^{46}$ This close reading indicates that the proverb was not an impediment to the Latin understanding of al-Ghazali, but instead was recognized as an important facet of addressing impression and emanation in general. The presence of this proverb in the Latin intellectual tradition stands as an eccentric testament to the project to understand the Arab Aristotelian tradition on its own terms and with its own idioms.

46 The scholars who treated impression as a philosophical concept appear to possess the Latin Maqāsid since the wording of the quotation matches closely what appears in al-Ghazali's text. Scholars whose wording of the proverb differed from what appears in the Latin Maqāsid were also those who implied that the concept of impression was magical. For example, the Condemnation of 1277 and the Malleus Malleficarum indicate that the camel is thrown into a 'foveam' rather than the 'caldarium' that appears in the Latin Maqāsid. This suggests that the authors of the condemnation and the Malleus may not have possessed the work and relied on other sources for their understanding of al-Ghazali. 